\title{
Defining the Glass Composition Limits for SRS Contaminated Soils (U)
}

\author{
by \\ C. A. Cicero \\ Westinghouse Savannah River Company \\ Savannah River Site \\ Aiken, South Carolina 29808 \\ W. O. Crews \\ Clemson University \\ SC USA \\ D. F. Bickford
}

A document prepared for THIRD BIENNIAL MIXED WASTE SYMPOSIUM at Baltimore from 08/08/95 - 08/11/95.

\section{DOE Contract No. DE-AC09-89SR18035}

This paper was prepared in connection with work done under the above contract number with the U. $S$. Department of Energy. By acceptance of this paper, the publisher and/or recipient acknowledges the U. S. Government's right to retain a nonexclusive, royalty-free license in and to any copyright covering this paper, along with the right to reproduce and to authorize others to reproduce all or part of the copyrighted paper. 
WSRC-MS-95- 60184
Revision 0

Keywords: RCRA, low level mixed wastes, vitrification

\title{
DEFINING THE GLASS COMPOSITION LIMITS FOR SRS CONTAMINATED SOILS
}

\section{by}

Connie A. Cicero and Dennis F. Bickford

Westinghouse Savannah River Company

Savannah River Technology Center

P.O. Box 616

Aiken, SC 29808

William O. Crews

Clemson University

Clemson Research Park

Anderson, SC 29634

A Paper Proposed for Publication in the Proceedings of the Third Biennial Mixed Waste Symposium, August 8 - 11, 1995, in Baltimore, Maryland.

\section{DISCLAIMER}

\begin{abstract}
This report was prepared as an account of work sponsored by an agency of the United States Government. Neither the United States Government nor any agency thereof, nor any of their employees, makes any warranty, express or implied, or assumes any legal liability or responsibility for the accuracy, completeness, or usefulness of any information, apparatus, product, or process disclosed, or represents that its use would not infringe privately owned rights. Reference herein to any specific commercial product, process, or service by trade name, trademark, manufacturer, or otherwise does not necessarily constitute or imply its endorsement, recommendation, or favoring by the United States Government or any agency thereof. The views and opinions of authors expressed herein do not necessarily state or reflect those of the United States Government or any agency thereof.
\end{abstract}

This paper was prepared in connection with work done under the U.S. Department of Energy - Office of Technology Development Technical Task Plan No. SR1-3-20-04. By acceptance of this paper, the publisher and/or recipient acknowledges the U.S. Government's right to retain a non-exclusive, royalty-free license in and to any copyright covering this paper, along with the right to reproduce and to authorize others to reproduce all or part of the copyrighted paper. 


\section{DISCLAIMER}

Portions of this document may be illegible in electronic image products. Images are produced from the best available original document. 


\title{
Defining the Glass Composition Limits for SRS Contaminated Soils
}

W.O. Crews, Jr., C.A. Cicero, and D.F. Bickford

\begin{abstract}
Contaminated soil resulting from the excavation, repair, and decommissioning of facilities located at the Savannah River Site (SRS) is currently being disposed of by shallow land burial or is being stored when considered only hazardous. Vitrification of this waste is being investigated, since it will bind the hazardous and radioactive species in a stable and durable glass matrix, which will reduce the risk of ground water contamination. However, the composition limits for producing durable glass have to be determined before the technology can be applied.
\end{abstract}

Glass compositions, consisting of SRS soil and glass forming additives, were tested on a crucible-scale in three ternary phase systems. Nine different glass compositions were produced, with waste loadings ranging from 43 to 58 weight percent. These were characterized using various chemical methods and tested for durability in both alkaline and acidic environments. All nine performed well in alkaline environments, but only three met the strictest criteria for the acidic environment tests. Although the glasses did not meet all of the limits for the acidic tests, the test was performed on very conservative size samples, so the results were also conservative. Therefore, enough evidence was found to provide proof that SRS soil can be vitrified in a durable glass matrix.

\section{INTRODUCTION}

Contaminated soils and similar contaminated concrete wastes resulting from the excavation, repair, and decommissioning of Separations, Reactor, and Interim Waste storage facilities located at the SRS are currently being disposed of by shallow land burial. These wastes can be contaminated as the result of hazardous chemical spills or low levels transuranic (TRU) element or mixed fission product releases. Vitrification of these materials, soil in particular, is being investigated since it will destroy the organic contaminants and bind the hazardous (RCRA metals) and radioactive species in the glass matrix. This reduces the risk of ground water contamination with the resulting wasteform being a stable and durable glass product.

Limited in-situ vitrification studies with simulated SRS contaminated soil were performed by Campbell and Buelt (1) of Pacific Northwest Laboratory. Their findings indicated that vitrification of the soil was plausible, but suggested that 
thorough additions of alkaline materials be made so a more homogeneous product would be produced and melting would be made easier.

Chemical analyses of uncontaminated SRS soil was performed by Looney et al. (2). The chemical composition of the SRS soil based on a dry oxide basis is given in Table 1.

\section{Place Table 1 Here}

When the in-situ tests were being performed, Campbell and Buelt chose to use typical contaminants that were found in SRS soils, since several SRS sites contain contaminated soil and they wanted to cover many waste streams. In their studies, they used the maximum contaminant levels based on levels found in their literature search and their equipment detection limits. They developed a simulated contaminated soil based on the data from Looney et al. (2) and these maximum concentrations. The contaminants selected for their experimentation is given in Table 2 .

\section{Place Table 2 Here}

In order to more directly apply vitrification technology to SRS contaminated soils, a better definition of the composition limits for producing durable glasses containing SRS soil needed to be determined. Various glass compositions had to be tested containing SRS soil and glass forming additives, which consist of fluxing agents and reactive chemicals. The intent of the studies were to optimize waste loading without sacrificing leach resistance and durability. The studies discussed in this paper were performed on a crucible-scale, and required several glass compositions to be tested to ensure that the glass forming region was completely covered. Since the studies were only performed on a crucible-scale, offgas analyses were not performed because offgas collection equipment is not normally used during crucible-scale testing in box furnaces.

\section{EXPERIMENTAL}

The soil characterization performed by Looney et al. (2) and the contaminant concentrations used by Campbell and Buelt (1) were also used for this study to make simulated SRS contaminated soil. The major difference between the two simulants used was the use of cerium in these studies as a stable simulant for cesium, cobalt, and strontium. (Nonradioactive cesium, cobalt, and strontium were not readily available, since cerium had been used in other mixed waste studies as the stable radioactive simulant, cerium was used in these studies). Cyanide was not added since it was present in such small amounts, and phenol was used as the organic material substitute because of the strict handing requirements enforced by SRS for the organics used by 
Campbell and Buelt. Table 3 lists the oxide components of the soil. Approximately 500 grams of this simulated soil were made from reagent grade chemicals for the crucible studies.

\section{Place Table 3 Here}

The surrogate soil composition was plotted on three different ternary phase diagrams: Calcia-Alumina-Silica (CAS), SodaLime-Silica (SLS), and Borosilicate (BOR). The types and amounts of additives necessary to make homogeneous glasses were determined based on the plots of the soil composition points. Several compositions were selected from each ternary diagram in order to try and maximize waste loading. Approximately 70 gram batches of the compositions shown in Table 4 were fabricated for testing, with the exception of BOR-7 and BOR-8 which were only 45 gram batches. After the batches were thoroughly mixed, they were placed in high purity (99.8\%) alumina crucibles and covered. The crucibles were placed in a programmable Lindberg furnace and melted for 4 hours at $1300^{\circ} \mathrm{C}$ for $B O R-4$ and the CAS system glasses and $1150^{\circ} \mathrm{C}$ for the SLS and BOR system glasses. After 4 hours at temperature, the crucibles were removed from the furnace and air-cooled to room temperature.

\section{Place Table 4 Here}

After cooling, the glasses were separated from the crucibles and analyzed for chemical composition, phase assemblage, and durability. Standards were submitted with each set of samples to determine the accuracy of the results. The total constituent analysis of the glasses was performed using Inductively Coupled Plasma - Emission Spectroscopy (ICPES) and Atomic Absorption (AA) spectrometry. The organic content of the glass was not analyzed because analytical techniques available at SRS would have destroyed the organics because of the elevated temperatures necessary to digest the glasses. $X$-ray Diffraction (XRD) analysis was performed to determine the crystalline phase assemblage in the glass and scanning Electron Microscopy (SEM) was used to confirm the XRD identification and chemical composition of the phases. Durability in an acidic environment was determined by performing the Toxicity Characteristic Leaching Procedure (TCLP), and the results were compared to the TCLP limits, the Resource Conservation and Recovery Act (RCRA) Land Disposal Limits, and the newly established Universal Treatment Standards (UTS), which became effective september 9, 1994.

The durability of the glass in an alkaline environment was determined by using the Product Consistency Test (PCT) per Jantzen et al (3). This test evaluates the chemical durability of homogeneous and devitrified glasses by measuring the concentrations of the chemical species released from a crushed glass to a test solution. The PCT is only 
required for high-level waste (HLW) glasses by the Department of Energy, but the results should provide a conservative estimate of glass durability for low-level mixed wastes (LLMW) glasses. The results were compared to the Environmental Assessment (EA) glass PCT results as characterized by Jantzen et al. (4), which are the acceptance criteria for HLW glasses.

\section{RESULTS AND DISCUSSION}

All of the sixteen batch compositions melted produced dark green glass. However, eight of the sixteen were covered with a white, crusty layer ranging in thickness from a few millimeters to several centimeters. These included batches CAS-1,2,3 and BOR-1,2,3,5,6. Of these eight, chemical analyses were performed only on batch CAS-3, which had the thinnest layer. XRD and SEM showed the layer to be high in silica, indicating that it was not completely reacted. In order to prevent the unreacted silica layer from forming, $\mathrm{Na}_{2} \mathrm{CO}_{3}$ was substituted as an additive for a portion of the $\mathrm{CaCO}_{3}$, since $\mathrm{Na}$ acts a better fluxing agent for $\mathrm{SiO}_{2}$.

The chemical compositions of the eight glasses and glass CAS3 are given in Table 5. Results for $\mathrm{Hg}$ are not included in the analyses, since it was only detected in trace amounts in one of the glasses. CAS-5 contained $49 \mu \mathrm{g} / 1$, while the remaining glasses contained $<30 \mu \mathrm{g} / \mathrm{L}$. This was expected since $\mathrm{Hg}$ is known to vaporize at high temperatures. All of the measured compositions were reasonably close to their expected values except for glasses CAS-3 and SLS-3. These differences were probably due to errors in batching. Since the analyzed compositions were used for all of the final analyses, these errors were not of a great concern and would only affect what the actual waste loading would be. Figures 1 - 3 show the location of the glasses on the applicable ternary phase diagrams.

Place Table 5 Here

Place Figure 1 Here

Place Figure 2 Here

Place Figure 3 Here

XRD analysis was performed in duplicate when sufficient quantities of the sample were available. The phases detected for each glass are shown in Table 6. The crystalline phases present in glass CAS-3 probably came from the unreacted silica layer. The quartz and cristobalite crystals detected in glasses $B O R-4$ and $B O R-7$ were present in minor amounts and did not seem to affect durability. The SEM performed on the samples confirmed the findings of the XRD analyses and did 
not reveal the presence of any large peaks of carbon, which would have possibly served as an indicator of the presence of organics in the glass.

\section{Place Table 6 Here}

TCLP extractions were performed on the glasses according to USEPA (5), and the resulting leachates were analyzed by ICPES. The TCLP was performed on $>150 \mu \mathrm{m}$ crushed glass, while the standard EPA tests are usually performed on larger size glass specimens $(1 \mathrm{~cm})$. Therefore, the results provided a conservative estimate of the leach resistance, since more glass surface area was exposed to the leaching solution. The results for the applicable metals are shown in Table 7 , along with the appropriate limits.

\section{Place Table 7 Here}

TCLP results show that the measured releases were less than the more conservative RCRA limits only for glasses SLS-1, SLS-2, and SLS-3. However, by applying the limits specified in the TCLP and considering the conservative nature of this test, glasses CAS-5 and BOR-7 were also considered acceptable. When the UTS limits were considered, all glasses met the $\mathrm{Ag}, \mathrm{Ba}$, and $\mathrm{Pb}$ limits, but only glasses SLS-1, SLS-2, and SLS-3 met all of the limits.

After the modified TCLP results were received, glass monoliths of the samples were placed in acetic acid for 24 hours to see how the glass integrity would be affected. This test simulated the TCLP leachant and surface area to volume ratio more closely than the modified test. None of the glasses showed any signs of degradation after 24 hours and the leachates had no detectable amounts of RCRA metals released when analyzed by ICPES. These observations lend support to the belief that these glasses may have been acceptable if the standard TCLP conditions were used, since the appropriate size glass specimen was used and no metals leached from the glass.

To assess the durability in alkaline conditions, the glasses were subjected to the PCT as developed by Jantzen et al. (3), which measures the releases of $\mathrm{B}, \mathrm{Na}, \mathrm{Si}$, and other elements in ASTM Type I water over a period of seven days at $90^{\circ} \mathrm{C}$. Each glass was run in triplicate for the PCT, and the results were averaged and then normalized using the analyzed elemental compositions. The blanks and standard glasses run simultaneously with the other glasses showed that no significant errors in the testing method occurred.

The average normalized releases and the leachate $\mathrm{pH}$ are given in Table 8 for each of the glasses and the EA glass per Jantzen et al. (4). As can be seen from the results, the normalized releases for all of the glasses were substantially 
less than the EA glass. No limit exists for Ce since it is not a critical component of high-level waste glasses, but its releases are shown since it was the radioactive simulant. Ce releases were very small for all of the glasses. Also, though they are not listed, the releases for the metals in the glasses were measured and found to be below or near detection limits $(<0.020 \mathrm{ppm} \mathrm{Ag},<0.001 \mathrm{ppm} \mathrm{Ba},<0.001 \mathrm{ppm}$ $\mathrm{Cd},<0.004 \mathrm{ppm} \mathrm{Cr},<0.005 \mathrm{ppm} \mathrm{Ni}$, and $<0.02 \mathrm{ppm} \mathrm{Pb})$.

\section{Place Table 8 Here}

\section{CONCIUSION}

Crucible studies with simulated contaminated SRS soil have shown that soil can be converted to a durable, leach resistant glass wasteform. Three glasses in the Soda-LimeSilica system (SLS-1, SLS-2, SLS-3) and one each in the Calcia-Alumina-Silica and Borosilicate systems (CAS-5 and BOR-7) passed all of the testing criteria. Waste loadings of up to 58 wto were obtained in the SLS system using glass forming additives of $\mathrm{CaCO}_{3}$ and $\mathrm{Na}_{2} \mathrm{CO}_{3}$, up to 48 wt: in the CAS system using $\mathrm{Al}_{2} \mathrm{O}_{3}, \mathrm{CaCO}_{3}$, and $\mathrm{Na}_{2} \mathrm{CO}_{3}$, and up to 43 wt: in the BOR system using $\mathrm{CaCO}_{3}, \mathrm{Na}_{2} \mathrm{CO}_{3}$, and borax. Higher waste loadings may have been possible if higher melting temperatures were used, but that was not performed in the scope of these studies.

Additional glass compositions may have also been acceptable, but because of the conservative sample size used to perform the TCLP, they were not considered acceptable in these studies. For the modified TCLP performed in these studies, the surface area of glass to volume of leachant ratio was magnitudes greater than it would have been for larger size glass specimen. The fact that these glasses did not leach any detectable amounts of RCRA metals into the acetic acid solutions after 24 hours lends proof to the notion that the glasses may have been acceptable.

\section{ACKNOWLEDGMENTS}

This work was sponsored under the South Carolina University Research and Education Foundation, which was funded through contract AA00900T. Funding for this contract was provided by the Department of Energy - Office of Technology Development Mixed Waste Integrated Program under operating contract No. DE-AC09-89SR18035.

\section{REFERENCES}

1. Campbell, B.E.; Buelt, J.I. In Situ Vitrification of Soil from the Savannah River Site. Richland, WA: Pacific Northwest Laboratory, PNL-7421; 1990. 
2. Looney, B.B.; Eddy, C.A.; Ramdeen, M.; Pickett, J. ; Rogers, V.; Shirley, P.A.; Scott, M.T. Geochemical and Physical Properties of Soils and Shallow Sediments at the Savannah River Site. Aiken, SC: Westinghouse Savannah River Company, WSRC-RP-90-0464; 1990.

3. Jantzen, C.M.; Bibler, N.E.; Beam, D.C.; Ramsey, W.G. Nuclear Waste Glass Product Consistency Test (PCT) Method - Version 7.0. Aiken, SC: Westinghouse Savannah River Company, WSRC-TR-90-539, Revision 3; 1994.

4. Jantzen, C.M.; Bibler, N.E.; Beam, D.C.; Crawford, C.L.; Pickett, M.A. Characterization of the Defense Waste Processing Facility (DWPF) Environmental Assessment (EA) Glass Standard Reference Material. Aiken, SC: Westinghouse Savannah River Company, WSRC-TR-92-346, Rev. 1; 1993.

5. USEPA (United States Environmental Protection Agency). Method 1131 Toxicity Characteristic Leaching Procedure (TCLP). 40 CER 261 Appendix II; 1991. 
Table 1 - Composition of Uncontaminated SRS Soil

Oxide

$\mathrm{Al}_{2} \mathrm{O}_{3}$

$\mathrm{CaO}$

$\mathrm{Fe}_{2} \mathrm{O}_{3}$

$\mathrm{K}_{2} \mathrm{O}$

$\mathrm{MnO}_{2}$

$\mathrm{Na}_{2} \mathrm{O}$

$\mathrm{P}_{2} \mathrm{O}_{5}$

$\mathrm{SiO}_{2}$

SrO

$\mathrm{TiO}_{2}$

$\mathrm{ZrO}_{2}$

Total
Dry Basis (wt 8$)$

4.8

0.4

0.77

0.13

0.01

0.05

1.12

92.5

0.001

0.4

0.09

100.271 
Table 2 - Concentrations of Hazardous and Radionuclide Simulants

$\begin{array}{cc}\text { Inorganic } & \text { Concentration } \\ \text { component } & \text { pom } \\ \mathrm{As} & 5 \\ \mathrm{Ba} & 310 \\ \mathrm{Cd} & 210 \\ \mathrm{Ce} & 2700 \\ \mathrm{Cs} & 450 \\ \mathrm{Cl} & 310 \\ \mathrm{Cr} & 2500 \\ \mathrm{Co} & 450 \\ \mathrm{Cu} & 190 \\ \mathrm{CN} & 15 \\ \mathrm{~F} & 3 \\ \mathrm{~Pb} & 320 \\ \mathrm{Hg} & 60 \\ \mathrm{Ni} & 370 \\ \mathrm{Ag} & 40 \\ \mathrm{Sr} & 4500 \\ \mathrm{NO} & 1700 \\ \mathrm{PO}_{4} & 1800 \\ \mathrm{SO}_{4} & 1100 \\ \text { Bis (2-ethylhexyl) } & 340 \\ \mathrm{Phthalate} & \\ \text { Methylene Chloridel } & 70\end{array}$


Table 3 - Surrogate Soil Composition

\begin{tabular}{cc} 
exide & Soil Wt \\
\hline $\mathrm{Ag}_{2} \mathrm{O}$ & 0.004 \\
$\mathrm{Al}_{2} \mathrm{O}_{3}$ & 4.696 \\
$\mathrm{BaO}$ & 0.034 \\
$\mathrm{CaO}$ & 0.391 \\
$\mathrm{CdO}$ & 0.023 \\
$\mathrm{CeO}_{2}$ & 1.375 \\
$\mathrm{Cr}_{2} \mathrm{O}_{3}$ & 0.357 \\
$\mathrm{CuO}_{2}$ & 0.023 \\
$\mathrm{Fe}_{2} \mathrm{O}_{3}$ & 0.753 \\
$\mathrm{HgO}_{\mathrm{K}} \mathrm{O}$ & 0.006 \\
$\mathrm{MnO}_{2}$ & 0.127 \\
$\mathrm{Na}_{2} \mathrm{O}$ & 0.010 \\
$\mathrm{NiO}$ & 0.049 \\
$\mathrm{P}_{2} \mathrm{O}_{5}$ & 0.046 \\
$\mathrm{PbO}$ & 1.096 \\
$\mathrm{SiO}_{2}$ & 0.034 \\
$\mathrm{TiO}_{2}$ & 90.496 \\
$\mathrm{ZrO}_{2}$ & 0.391 \\
$\mathrm{Total}^{2}$ & 0.088 \\
& 99.999
\end{tabular}


Table 4 - Batch Compositions By Weight Percentages

\begin{tabular}{|c|c|c|c|c|c|}
\hline Batch & soil & $\mathrm{Al}_{2} \mathrm{O}_{3}$ & $\mathrm{CaCO}_{3}$ & $\mathrm{Na}_{2} \mathrm{CO}_{3}$ & Borax \\
\hline CAS-1 & 50 & 10 & 40 & 0 & $\mathrm{~N} / \mathrm{A}$ \\
\hline CAS-2 & 58 & 7 & 35 & 0 & $\mathrm{~N} / \mathrm{A}$ \\
\hline CAS-3 & 40 & 15 & 45 & 0 & $N / A$ \\
\hline CAS-4 & 40 & 15 & 25 & 20 & $\mathrm{~N} / \mathrm{A}$ \\
\hline CAS-5 & 48 & 7 & 30 & 15 & $N / A$ \\
\hline SLS-1 & 55 & 0 & 20 & 25 & $N / A$ \\
\hline SLS-2 & 58 & 0 & 17 & 25 & $N / A$ \\
\hline SLS -3 & 55 & 0 & 15 & 30 & $\mathrm{~N} / \mathrm{A}$ \\
\hline BOR-1 & 50 & $\mathrm{~N} / \mathrm{A}$ & 25 & 0 & 25 \\
\hline BOR -2 & 50 & $\mathrm{~N} / \mathrm{A}$ & 20 & 0 & 30 \\
\hline $\mathrm{BOR}-3$ & 45 & $\mathrm{~N} / \mathrm{A}$ & 25 & 0 & 30 \\
\hline BOR-4 & 50 & $N / A$ & 25 & 0 & 25 \\
\hline BOR-5 & 43 & $N / A$ & 17 & 0 & 40 \\
\hline BOR-6 & 52 & $N / A$ & 15 & 0 & 33 \\
\hline BOR -7 & 43 & $N / A$ & 10 & 7 & 40 \\
\hline BOR -8 & 43 & $N / A$ & 15 & 10 & 32 \\
\hline
\end{tabular}


Table 5 - Oxide Composition of the Soil Glasses

\begin{tabular}{|c|c|c|c|c|c|}
\hline Oxide & CAs-3 & CAS-4 & CAS-5 & $S I_{S} S-1$ & $S I S-2$ \\
\hline $\mathrm{Ag}_{2} \mathrm{O}$ & 0.003 & 0.002 & 0.002 & 0.002 & 0.002 \\
\hline $\mathrm{Al}_{2} \mathrm{O}_{3}$ & 2.201 & 23.095 & 14.308 & 2.140 & 1.847 \\
\hline $\mathrm{B}_{2} \mathrm{O}_{3}$ & 0.017 & 0.013 & 0.101 & 0.013 & 0.013 \\
\hline $\mathrm{BaO}$ & 0.034 & 0.029 & 0.057 & 0.019 & 0.025 \\
\hline $\mathrm{CaO}$ & 12.926 & 16.589 & 20.444 & 13.752 & 11.491 \\
\hline $\mathrm{CdO}$ & 0.014 & 0.001 & 0.010 & 0.004 & 0.013 \\
\hline $\mathrm{CeO}_{2}$ & 0.470 & 0.378 & 0.404 & 0.586 & 0.301 \\
\hline $\mathrm{Cr}_{2} \mathrm{O}_{3}$ & 0.341 & 0.072 & 0.154 & 0.175 & 0.297 \\
\hline Cuo & 0.001 & 0.001 & 0.018 & 0.001 & 0.001 \\
\hline $\mathrm{Fe}_{2} \mathrm{O}_{3}$ & 1.175 & 1.518 & 3.081 & 0.585 & 1.194 \\
\hline $\mathrm{K}_{2} \mathrm{O}$ & 0.074 & 0.045 & 0.050 & 0.084 & 0.090 \\
\hline $\mathrm{MnO}_{2}$ & 0.010 & 0.028 & 0.051 & 0.001 & 0.012 \\
\hline $\mathrm{Na}_{2} \mathrm{O}$ & 0.114 & 13.620 & 10.221 & 17.300 & 17.171 \\
\hline $\mathrm{NiO}$ & 0.116 & 0.096 & 0.230 & 0.048 & 0.126 \\
\hline $\mathrm{P}_{2} \mathrm{O}_{5}$ & 1.154 & 1.107 & 1.411 & 0.816 & 0.912 \\
\hline $\mathrm{PbO}$ & 0.031 & 0.023 & 0.074 & 0.024 & 0.020 \\
\hline $\mathrm{SiO}_{2}$ & 81.087 & 44.569 & 53.570 & 63.588 & 66.487 \\
\hline $\mathrm{TiO}_{2}$ & 0.194 & 0.217 & 0.276 & 0.160 & 0.159 \\
\hline $\mathrm{ZrO}_{2}$ & 0.041 & 0.057 & 0.069 & 0.032 & 0.034 \\
\hline Total & 100.003 & $10 \overline{1.461}$ & $10 \overline{4.531}$ & 99.330 & 100.203 \\
\hline
\end{tabular}

\begin{tabular}{|c|c|c|c|c|}
\hline oxide & $S I S-3$ & BOR-4 & $\mathrm{BOR}-7$ & BOR-8 \\
\hline $\mathrm{Ag}_{2} \mathrm{O}$ & 0.002 & 0.006 & 0.002 & 0.002 \\
\hline $\mathrm{Al}_{2} \mathrm{O}_{3}$ & 18.034 & 10.235 & 7.973 & 10.353 \\
\hline $\mathrm{B}_{2} \mathrm{O}_{3}$ & 0.010 & 12.030 & 19.401 & 16.446 \\
\hline $\mathrm{BaO}$ & 0.011 & 0.026 & 0.057 & 0.033 \\
\hline $\mathrm{CaO}$ & 25.237 & 18.296 & 7.618 & 12.011 \\
\hline $\mathrm{CdO}$ & 0.001 & 0.005 & 0.008 & 0.008 \\
\hline $\mathrm{CeO}_{2}$ & 0.164 & 0.634 & 0.369 & 0.437 \\
\hline $\mathrm{Cr}_{2} \mathrm{O}_{3}$ & 0.160 & 0.199 & 0.104 & 0.097 \\
\hline CuO & 0.001 & 0.001 & 0.017 & 0.010 \\
\hline $\mathrm{Fe}_{2} \mathrm{O}_{3}$ & 0.659 & 0.823 & 2.170 & 1.922 \\
\hline $\mathrm{K}_{2} \mathrm{O}$ & 0.073 & 0.083 & 0.047 & 0.043 \\
\hline $\mathrm{MnO}_{2}$ & 0.005 & 0.005 & 0.044 & 0.030 \\
\hline $\mathrm{Na}_{2} \mathrm{O}$ & 17.142 & 5.350 & 13.279 & 14.767 \\
\hline NiO & 0.079 & 0.050 & 0.143 & 0.122 \\
\hline $\mathrm{P}_{2} \mathrm{O}_{5}$ & 0.488 & 1.524 & 1.405 & 1.446 \\
\hline $\mathrm{PbO}$ & 0.019 & 0.023 & 0.064 & 0.062 \\
\hline $\mathrm{SiO}_{2}$ & 37.803 & 51.549 & 50.300 & 42.768 \\
\hline $\mathrm{TiO}_{2}$ & 0.087 & 0.299 & 0.292 & 0.305 \\
\hline $\mathrm{ZrO}_{2}$ & 0.023 & 0.085 & 0.074 & 0.073 \\
\hline Total & 99.998 & 101.222 & 103.367 & 100.936 \\
\hline
\end{tabular}


Figure 1 - $\mathrm{CaO}-\mathrm{Al}_{2} \mathrm{O}_{3}-\mathrm{SiO}_{2}$ Ternary Diagram

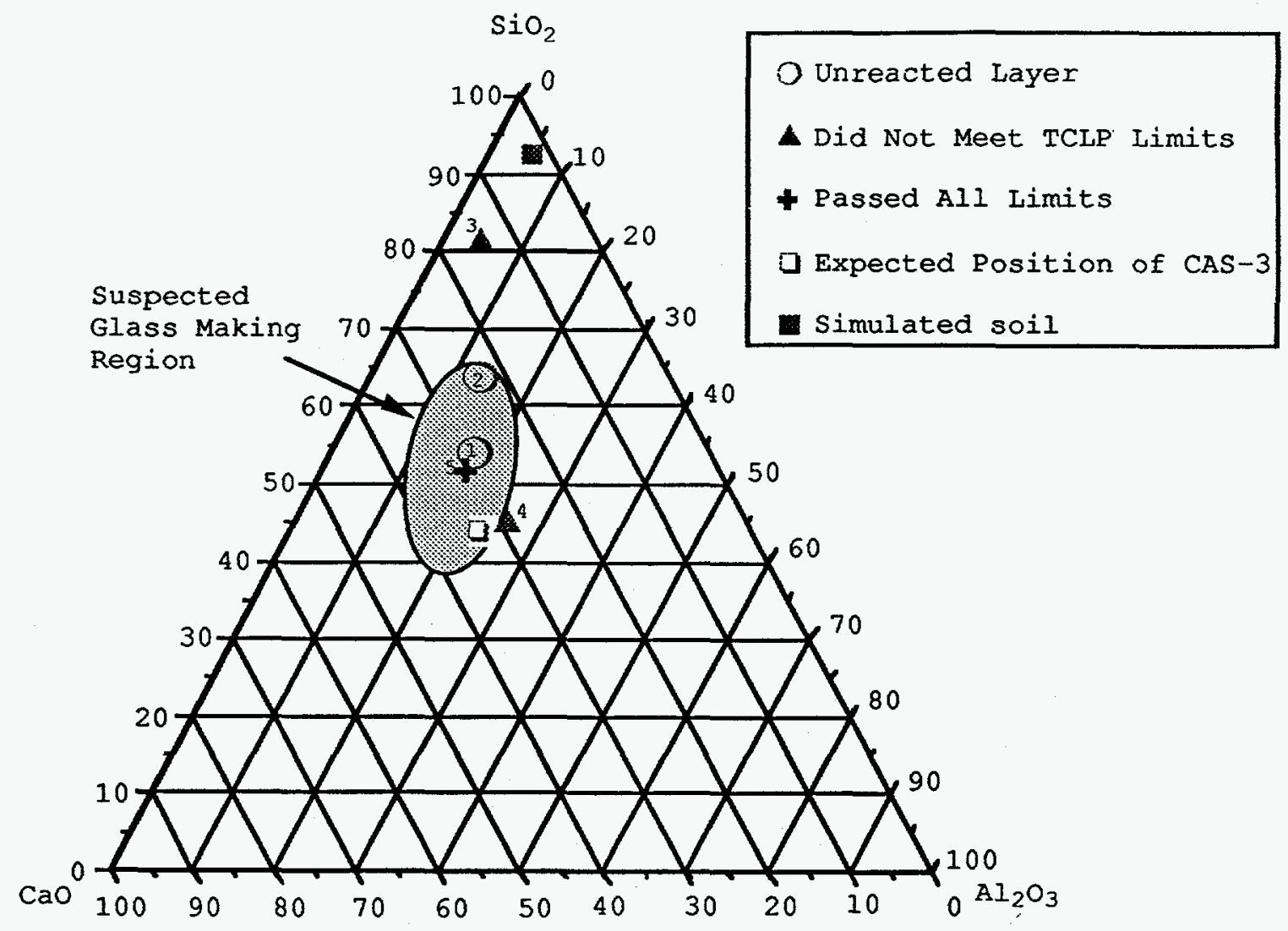




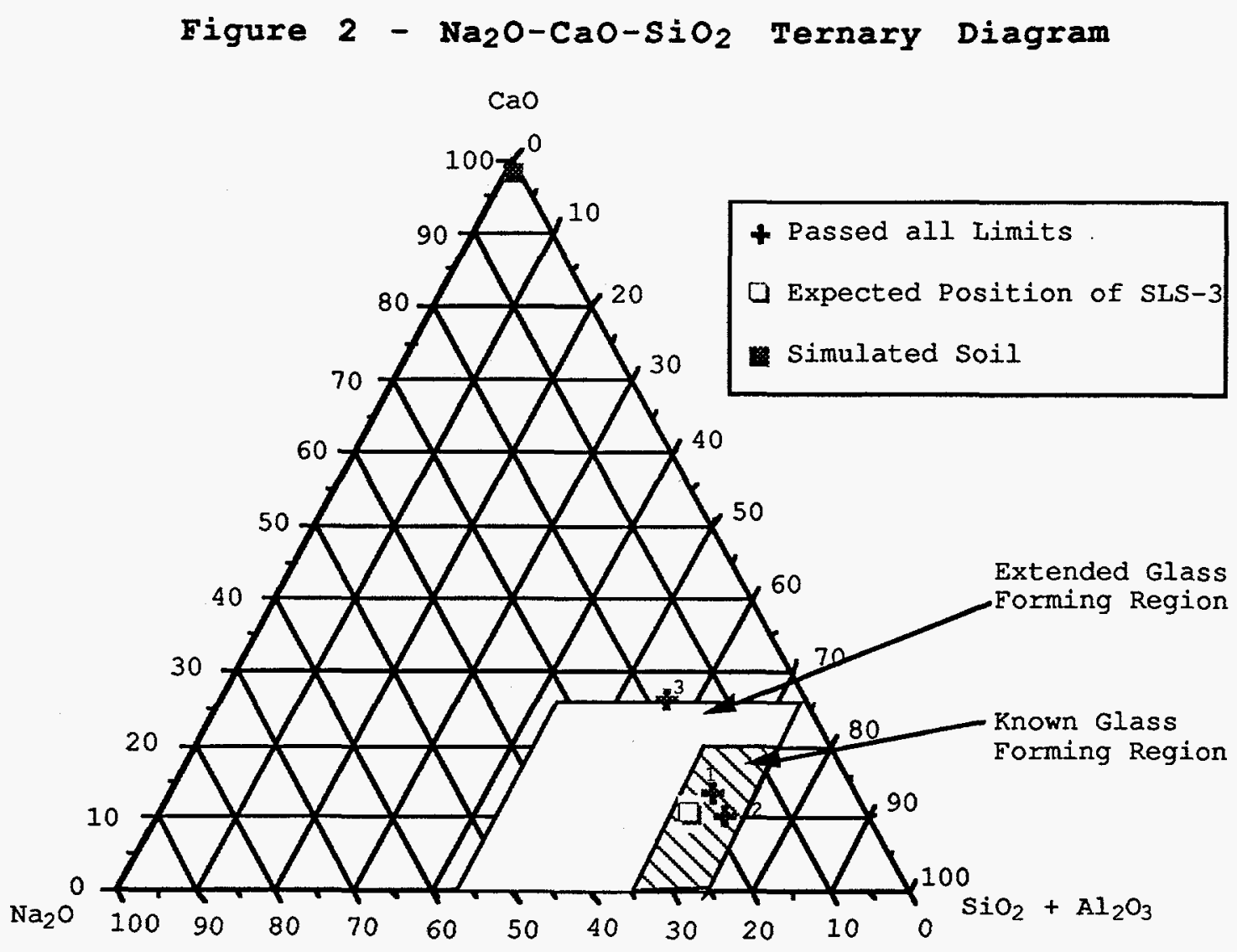




\section{Figure 3 - Borosilicate Ternary Diagram}

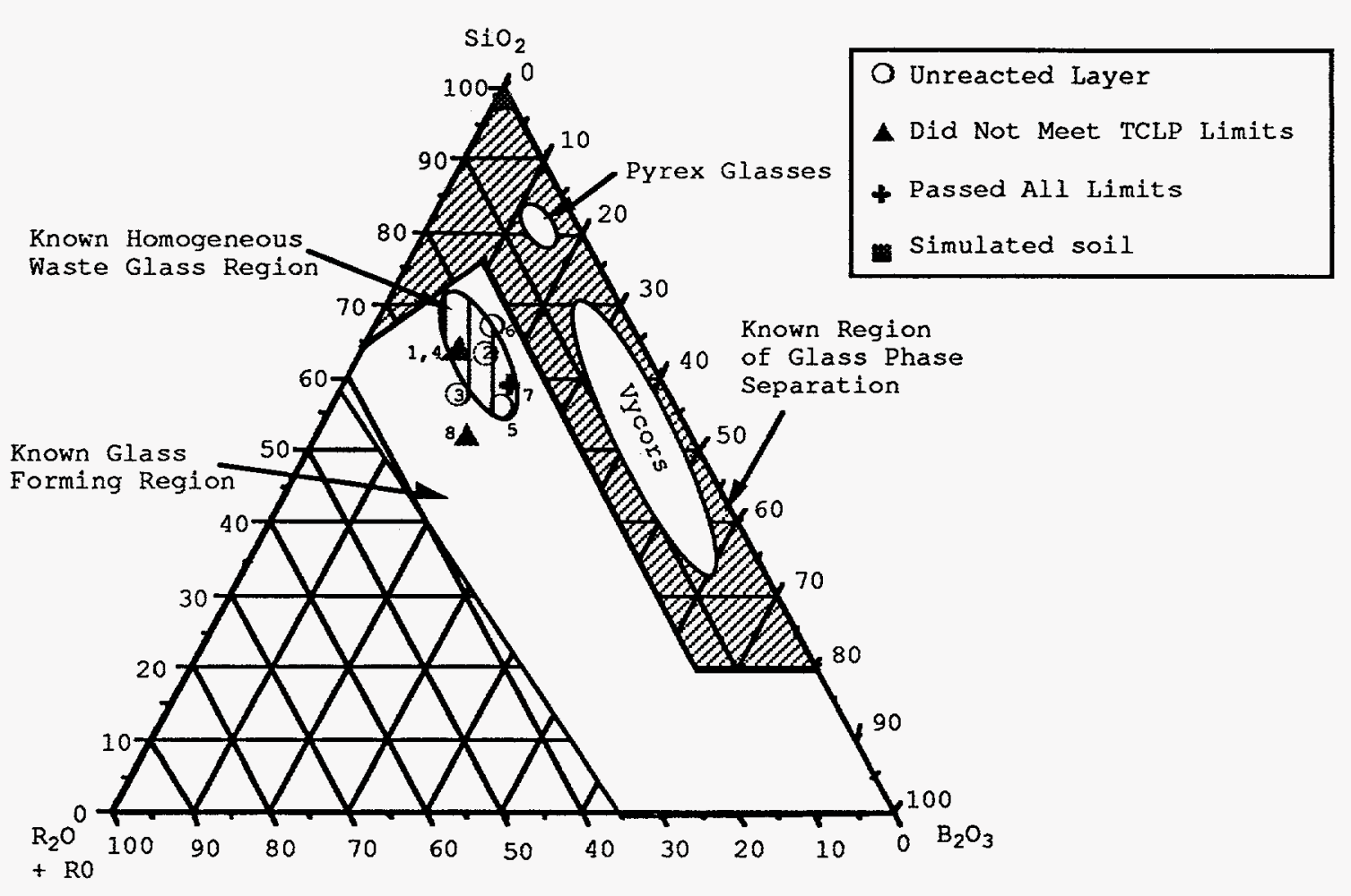


Table 6 - XRD Phase Assemblage Results

Batch

CAS-3

CAS -4

CAS -5

SLS -1

SLS-2

SLS -3

BOR-4

BOR -7

BOR -8

\section{Analysis 1}

0.3 wt\% Quartz 0.4 wt\% Gehlenite

Amorphous

Amorphous

Amorphous

Amorphous

Amorphous

1.6 wt: Quartz

0.9 wt: Cristobalite

0.1 wt: Quartz

Amorphous

\section{Analysis 2}

0.2 wt: Quartz

0.5 wt: Gehlenite

0.1 wto Anorthite Amorphous

Amorphous

Amorphous

Amorphous

Amorphous

2.0 wt\% Quartz

0.8 wt: Cristobalite

$\mathrm{N} / \mathrm{A}$

$\mathrm{N} / \mathrm{A}$ 
Table 7 - TCLP Results (mg/L)

\begin{tabular}{|c|c|c|c|c|c|c|}
\hline Batch & Ag & $\mathbf{B a}$ & cd & c.x & $\mathrm{Ni}$ & Pb \\
\hline CAS-3 & $<0.020$ & 1.540 & $0 . \overline{720}$ & 9.530 & $1 . \overline{436}$ & 1.989 \\
\hline CAS -4 & $<0.020$ & 6.265 & 1.102 & 15.777 & 1.934 & 4.694 \\
\hline CAS-5 & $<0.020$ & 3.607 & 0.088 & 1.234 & 0.113 & $<0.200$ \\
\hline SLS-1 & $<0.020$ & 0.549 & $<0.010$ & $<0.040$ & $<0.050$ & $<0.200$ \\
\hline SLS-2 & $<0.020$ & 0.527 & $<0.010$ & $<0.040$ & $<0.050$ & $<0.200$ \\
\hline SLS-3 & $<0.020$ & 0.527 & 0.012 & 0.103 & $<0.050$ & $<0.200$ \\
\hline BOR-4 & $<0.020$ & 2.441 & 0.914 & 8.440 & 1.464 & 1.770 \\
\hline BOR-7 & $<0.020$ & 1.581 & 0.947 & 3.918 & 1.104 & 1.548 \\
\hline BOR-8 & 0.269 & 4.807 & 1.700 & 13.163 & 1.646 & 2.675 \\
\hline CRA & 0.072 & $N / A$ & 0.066 & 5.2 & 0.32 & 0.51 \\
\hline CLP & 5 & 100 & 1.00 & 5.00 & $\mathrm{~N} / \mathrm{A}$ & 5.00 \\
\hline UTS & 0.30 & 7.6 & 0.19 & 0.86 & 5.00 & 0.37 \\
\hline
\end{tabular}


Table 8 - Normalized PCT Results (g/L)

$\begin{array}{cccccc}\text { Batch } & \mathbf{B} & \mathbf{N a} & \mathbf{S i} & \mathbf{c e} & \mathbf{p H} \\ \text { CAS-3 } & 0.000 & 0.296 & 0.033 & 0.008 & 10.75 \\ \text { CAS-4 } & 0.000 & 0.321 & 0.087 & 0.019 & 10.86 \\ \text { CAS-5 } & 0.000 & 0.276 & 0.076 & 0.010 & 10.73 \\ \text { SLS-1 } & 8.335 & 3.345 & 0.589 & 0.095 & 12.10 \\ \text { SLS-2 } & 3.612 & 4.346 & 0.770 & 0.136 & 12.18 \\ \text { SLS-3 } & 2.898 & 9.418 & 3.150 & 0.247 & 12.45 \\ \text { BOR-4 } & 0.190 & 0.189 & 0.050 & 0.006 & 10.10 \\ \text { BOR-7 } & 1.905 & 1.829 & 0.462 & 0.011 & 9.62 \\ \text { BOR-8 } & 0.559 & 0.643 & 0.064 & 0.009 & 10.14 \\ \text { EA } & 16.695 & 13.346 & 3.922 & \text { N/A } & 11.91\end{array}$

